\title{
Substituted pyrrolo[1,2-a][1,2,4]triazolo-(triazino-)[c]quinazolines - a promising class of lipoxygenase inhibitors
}

\author{
V. V. Stavytskyi ${ }^{\star A-D}$, I. S. NosulenkoC, O. O. Portna ${ }^{B}$, V. M. Shvets ${ }^{D}$, O. Yu. Voskoboinik ${ }^{A}$, S. I. Kovalenko ${ }^{\mathrm{E}, F}$ \\ Zaporizhzhia State Medical University, Ukraine
}

A - research concept and design; B - collection and/or assembly of data; C - data analysis and interpretation; D - writing the article; $\mathrm{E}$ - critical revision of the article; $\mathrm{F}-$ final approval of the article

The modern strategy of potential biologically active molecules search ("drug-design") is based on several innovation approaches. The method of high throughput biological screening and method of molecular modeling deserves the most attention among such approaches. Lipoxygenase (LOX) is one of the most perspective biological target for the substituted pyrrolo[1,2-a][1,2,4]triazolo-(triazino-)[c]quinazolines. So, molecular docking towards LOX and enzyme activating activity was investigated.

The aim: Directed search of potential inhibitors of lipoxygenases among the unknown pyrrolo[1,2-a][1,2,4]triazolo-(triazino-)[c]quinazolines with the use of molecular docking and in vitro high throughput screening.

Materials and methods. The research of lipoxygenase activity has been conducted for a number of original pyrrolo[1,2-a][1,2,4]triazolo-(triazino-)[c]quinazolines. Standard software was used for molecular docking and "drug-like" criteria research. Sodium letinate was used as a substrate to study soybean LOX enzyme activating activity.

Results. The results of molecular docking have shown, that substituted pyrrolo[1,2-a][1,2,4]triazolo[1,5-c]quinazolines reveal a strong affinity toward LOX. The main types of interactions with aminoacid residues of mentioned the enzyme were identified. The conducted researches showed, that the substituted pyrrolo[1,2-a][1,2,4]triazino[2,3-c]quinazolines had the highest soybean LOX inhibition activity. Compounds with a fluorine atom and a 2-thienyl moiety in the structure revealed the highest activity inhibiting lipoxygenase by $36.33 \%$ and $39.83 \%$ respectively. The increased lipophilicity of triazine derivatives promotes a higher ability to inhibit soybean LOX, whereas, for triazole derivatives, which have lower molecular weight, an inverse relation is observed.

Conclusions. The research of the substituted pyrrolo[1,2-a][1,2,4]triazolo-(triazino-)[c]quinazolines inhibition ability of soybean LOX as one of the possible mechanisms of their activity is proved and conducted. It is shown, that their lipoxygenase activity depends on lipophilicity and is defined by the availability of donor-acceptor fragments in the molecule, that is capable to form hydrogen and other types of interaction. The specified results are strong arguments for their further study as promising anti-inflammatory agents.

Заміщені піроло[1,2-а][1,2,4]тріазоло-(тріазино-)[с]хіназоліни - перспективний клас інгібіторів ліпоксигенази

\section{В. В. Ставицький, І. С. Носуленко, О. О. Портна, В. М. Швець, О. Ю. Воскобойнік, С. І. Коваленко}

Сучасна стратегія пошуку потенційних біологічноактивних молекул заснована на низці інноваційних підходів, серед них на особливу увагу заслуговують методи високоефективного біологічного скринінгу та молекулярного моделювання. Одна з перспективних біологічних мішеней для ряду заміщених піроло[1,2-а][1,2,4]тріазоло-(тріазино-)[с]хіназолінів - ліпоксигеназа (ЛОГ), щодо якої здійснили молекулярний докінг та експериментально дослідили ензим-активувальну активність.

Мета роботи - спрямований пошук потенційних інгібіторів ЛОГ серед невідомих піроло[1,2-а][1,2,4]тріазоло-(тріазино-)[с]хіназолінів, використовуючи молекулярний докінг і високоефективний скринінг in vitro.

Матеріали та методи. Для досліджень обрали ряд заміщених піроло[1,2-а][1,2,4]тріазоло-(тріазино-)[с]хіназолінів. Для молекулярного докінгу та визначення відповідності критеріям «лікоподібності» використали стандартне програмне забезпечення. Дослідження ензим-активувальної активності здійснили на соєвій ЛОГ з використанням натрію ленолінату як субстрату.

Результати. Здійснили докінгове дослідження заміщених піроло[1,2-а][1,2,4]тріазоло-(тріазино-)[с]хіназолінів. 3'ясували, що цей клас сполук має суттєву спорідненість до ЛОГ. Визначили основні типи взаємодій з амінокислотними залишками цього ферменту. Дослідження щодо інгібування соєвої ЛОГ показали, що серед сполук, що досліджували, найбільш активними були заміщені піроло[1,2-а][1,2,4]тріазино[2,3-с]хіназолінів. Серед них найвищу інгібувальну активність мають сполуки з атомом Флуору та 2-тіенільним фрагментом у молекулі (36,33 \% та 39,83 \% відповідно). Зі збільшенням ліпофрільності здатність похідних тріазину до інгібування соєвої ЛОГ збільшується, а для похідних тріазолу, які мають значно меншу молекулярну масу, спостерігали зворотну залежність.

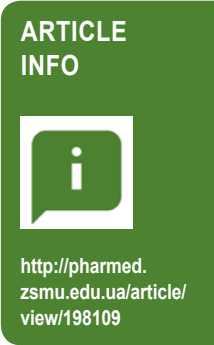

UDC 547.792'856:577.15

DOI: 10.14739/2409-2932.2020.1.198109

Current issues in pharmacy and medicine: science and practice 2020; 13 (1), 4-10

Key words: drug discovery, pyrrolo[1,2-a][1,2,4]triazolo-(triazino-)[c]quinazolines, molecular docking, lipoxygenase activity.

*E-mail: v.v.stavytskyi@gmail.com

Received: 06.12.2019 // Revised: 16.12.2019 // Accepted: 20.12.2019 
Висновки. Обґрунтували та дослідили заміщені піроло[1,2-a][1,2,4]тріазоло-(тріазино-)[c]хіназолінів щодо здатності інгібування соєвої ЛОГ як один із можливих механізмів дії. Їхня ліпоксигеназна активність залежить від ліпофільності та визначається наявністю в молекулі донорно-акцепторних фрагментів, що здатні до утворення водневих зв'язків та інших типів взаємодій. Результати дослідження - вагомий аргумент для вивчення цих сполук надалі як перспективних протизапальних агентів.

Ключові слова: розробка лікарських засобів, піроло[1,2-а][1,2,4]тріазоло-(тріазино-)[c]хіназоліни, молекулярний докінг, ліпоксигеназна активність.

Актуальні питання фрармацевтичної і медичної науки та практики. 2020. Т. 13, № 1(32). С. 4-10

Замещенные пирроло[1,2-а][1,2,4]триазоло-(триазино-)[с]хиназолины - перспективный класс ингибиторов липоксигеназы

\section{В. В. Ставицкий, И. С. Носуленко, Е. А. Портная, В. Н. Швец, А. Ю. Воскобойник, С. И. Коваленко}

Современная стратегия поиска потенциальных биологически активных веществ основана на ряде инновационных подходов, среди которых особого внимания заслуживают методы высокоэффеектиного биологического скрининга и молекулярного моделирования. Одна из перспективных биологических мишеней для ряда замещенных пирроло[1,2-a][1,2,4]триазоло-(триазино-)[c] хиназолинов - липоксигеназа (ЛОГ), по отношению к которой проведен молекулярный докинг и экспериментально исследована энзим-активирующая активность.

Цель работы - направленный поиск потенциальных ингибиторов ЛОГ среди неизвестных пирроло[1,2-а][1,2,4]триазоло-(триазино-)[c]хиназолинов с использованием молекулярного докинга и высокоэффективного скрининга in vitro.

Материалы и методы. Для исследований отобран ряд замещенных пирроло[1,2-a][1,2,4]триазоло-(триазино-)[c]хиназолинов. Для молекулярного докинга и критериев «лекарствоподобия» использовано стандартное программное обеспечение. Исследование энзим-активирующей активности проведено на соевой ЛОГ с использованием натрий ленолината в качестве субстрата.

Результаты. Замещенные пирроло[1,2-а][1,2,4]триазоло-(триазино-)[c]хиназолин подвергнуты докинговому исследованию, которое показало, что этот класс соединений имеет значительную аффинность к ЛОГ. Определены основные типы взаимодействий с аминокислотными остатками указанного фермента. Исследования по ингибированию соевой ЛОГ показали, что среди изучаемых соединений наиболее активными оказались замещенные пирроло[1,2-a][1,2,4]триазино[2,3-с]хиназолины. Среди них наиболее высокое ингибирующее действие проявляют соединения с атомом фтора и 2-тиенильным фррагментом в молекуле (36,33 \% и 39,83 \% соответственно). С увеличением липофильности способность производных триазина к ингибированию соевого ЛОГ увеличивается, а для производных триазола, которые имеют значительно меньшую молекулярную массу, отмечена обратная зависимость.

Выводы. Обосновано и проведено исследование замещенных пирроло[1,2-а][1,2,4]триазоло-(триазино-)[c]хиназолинов на способность ингибировать соевую ЛОГ как один из возможных механизмов действия. Их липоксигеназная активность зависит от липофильности и определяется наличием в молекуле донорно-акцепторных фрагментов, способных к образованию водородной связи и других типов взаимодействий. Результаты являются весомым аргументом для их дальнейшего изучения как перспективных противовоспалительных агентов.

Ключевые слова: разработка лекарственных средств, пирроло[1,2-a][1,2,4]триазоло-(триазино-)[с]хиназолины, молекулярный докинг, липоксигеназная активность.

Актуальные вопросы фармацевтической и медицинской науки и практики. 2020. Т. 13, № 1(32). С.4-10

The modern strategy of potential biologically active molecules search ("drug-design") underwent significant changes and became the most important part of modern medical chemistry [1-3]. Now it is based on several innovation approaches, such as virtual screening, combinatory chemistry, high throughput screening, molecular modeling, fragment-oriented design, optimization of the leading structure, etc. Among the above-mentioned approaches, the method of high throughput biological screening deserves the most attention. This method allows estimating activity of many compounds against a known biological target in short terms. Structures of biological targets are known. With the help of them, the molecular mechanism of interaction of the ligand with protein could be explained. So, they are used for molecular docking [4-6]. Protein three-dimensional structure (at the current stage of technology development, as a rule conformationally rigid) and structure of ligand (the known inhibitor and synthesized compound) are used as a starting information for docking. The optimal ligand conformation with a specific binding energy value for the biological target is the docking result. Using this results perspective objects for further high throughput screening could be revealed. In view of many approximations, the binding energy does not always correlate with the relevant experimental data. However, it gives an understanding of the mechanism and ligand activity efficiency.

Throughout the directed search investigatements of biologically active compounds among quinazoline derivatives and its condensed analogs [7-16], we have used the above-mentioned strategy. Lipoxygenase (LOX) was used as a biological target. Especially, considering that LOX part in many pathological conditions formation, such as chronic inflammations, allergy, asthma, some cancer types, cardiovascular diseases, etc [17].

\section{Aim}

So, the purpose of work is the directed search of lipoxygenases potential inhibitors among the unknown pyrrolo[1,2-a] 


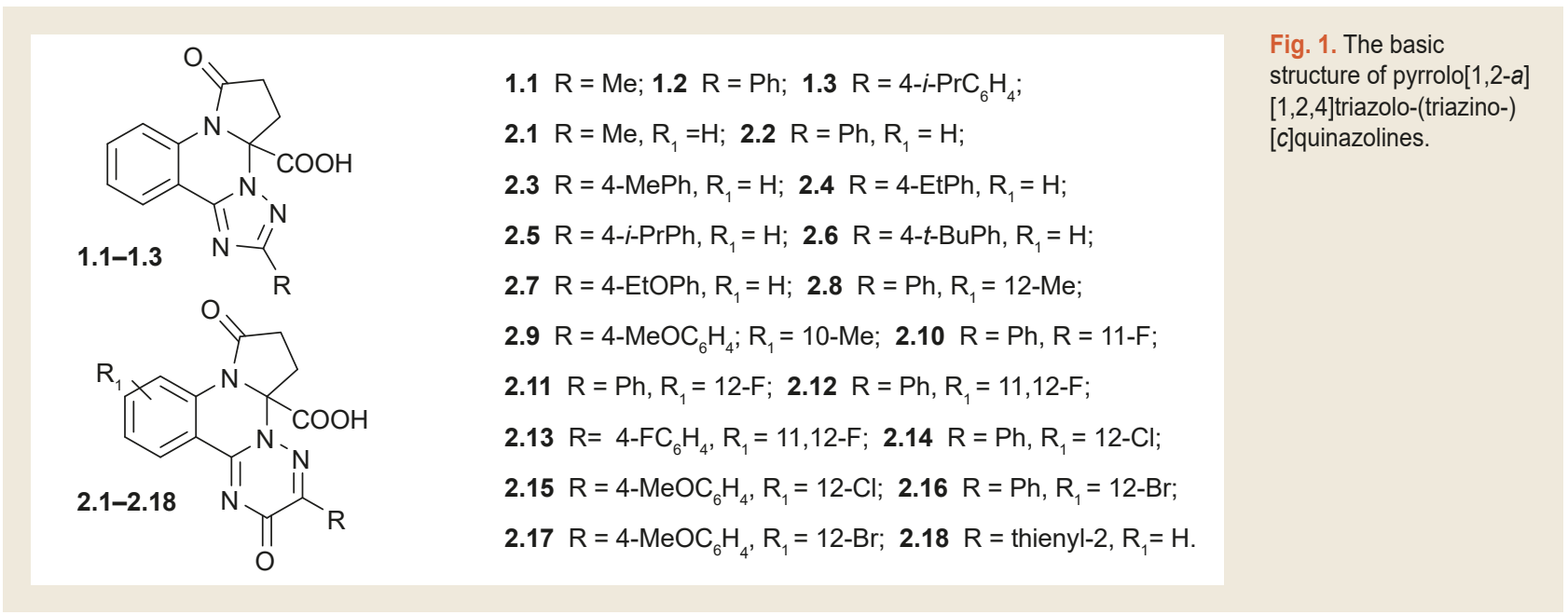

$[1,2,4]$ triazolo-(triazino-) $[c]$ quinazolines with the molecular docking usage and in vitro highly effective screening.

\section{Materials and methods}

The research of lipoxygenase activity has been conducted for a number of original pyrrolo[1,2- $a][1,2,4]$ triazolo-(triazino-)[c]quinazolines 1.1-1.3, 2.1-2.18 (Fig. 1), which were synthesized at the Department of Organic and Bioorganic Chemistry of the Zaporizhzhia state medical university (the Head of the Department, Dr.hab., Professor, S. I. Kovalenko). The features of the structures of the synthesized compounds were evaluated by IR-, NMR spectroscopy, and chromatography-mass spectrometry and were discussed in detail [18].

Molecular docking. The research was conducted by flexible molecular docking, as an approach of finding molecules with affinity to a specific biological target. Macromolecules from Protein Data Bank (PDB) were used as biological targets, namely LOX (soybean) enzyme in complex with protocatechuic acid (PDB ID - 1N8Q) [19]. The choice of biological targets was due to the literature on the mechanism of anti-inflammatory drug action [17].

Ligand preparation. Substances were drawn using MarvinSketch 19.24 and saved in mol format [20]. After that, they were optimized by program Chem3D, using the molecular mechanical MM2 algorithm and saved as pdb-files. Molecular mechanics was used to producing more realistic geometry values for the majority of organic molecules, owing to the fact of being highly parameterized. Using AutoDockTools-1.5.6 pdb-files were converted into PDBQT, the number of active torsions was set as default [21].

Protein preparation. PDB files were downloaded from the protein data bank. Discovery Studio v 19.1.0.18287 was used to delete water molecules and ligands. Structures of proteins were saved as pdb-files [22]. In AutoDockTools-1.5.6 polar hydrogens were added and saved as PDBQT. Grid box was set as following: center_ $\mathrm{x}=18.370$, center_y $=-52.296$, center $\_z=53.949$, size $\_x=18$, size $y=16$, size $z=16$ for COX-2 (3LN1); center $\mathrm{x}=32.978$, center $\mathrm{y}=-44.488$, center $z=-3.760$, size $x=16$, size $y=16$, size $z=16$ for
COX-1 (3N8Y). Vina was used to carry docking [15]. For visualization Discovery Studio v 19.1.0.18287 was used.

Lipinski's rule of five. Drug-like characteristics (Log P, molecular polar surface area, number of non-hydrogens, number of hydrogen bond acceptors (groups $\mathrm{N}$ and $\mathrm{O}$ ), number of hydrogen bond donors (groups $\mathrm{NH}$ and $\mathrm{OH}$ ) and number of rotatable bonds) were evaluated and optimized using an electronic resource [23].

Soybean LOX inhibition study in vitro. In vitro study was evaluated as it was reported previously $[24,25]$. To $3.880 \mathrm{ml}$ of borate buffer, $40 \mu \mathrm{l} 2 \times 10^{-5} \mathrm{w} / \mathrm{v}$ solution of LOX in the buffer and $40 \mu \mathrm{l}$ of $100 \mathrm{uM}$ studied compound (or nordihydroguaiaretic acid (NDGA)) solution were added. The formed mixture was shaken and incubated at ambient temperature for $5 \mathrm{~min}$. After incubation, the $40 \mu \mathrm{l}$ of 0.01 M solution of sodium linoleate was added. After $20 \mathrm{~min}$. incubated at ambient temperature absorption at $234 \mathrm{~nm}$ was recovered. The results are calculated by the formula:

LOX inhibiting activity, $\%=\left(\mathrm{A}_{\text {control }-} \mathrm{A}_{\text {test compound }}\right) /$ $\mathrm{A}_{\text {control }} \times 100 \%$

\section{Results}

The results of molecular docking have shown, that substituted pyrrolo[1,2- $a][1,2,4]$ triazolo[1,5-c]quinazolines (1.1-1.3) have a strong affinity for LOX (Table 1). So, their affinity is much higher, than protocatechuic acid has, a known LOX inhibitor. However, their binding energy is weaker then NDGA, which is used as the pharmacological standard. Binding energy of substituted pyrrolo[1,2- $a][1,2,4]$ triazino[2,3-c] quinazolines (2.1-2.18) approach to NDGA value and compounds 2.6, 2.8, 2.18 binding energy exceed it.

However, high affinity to specified enzymes is not always the main factor for activity revealing. It may be due to the influence of additional factors (lipophilicity, metabolism, etc.), which are described by the «drug-like» criteria ( $\mathrm{Ta}$ ble 2). Analysis of "drug-like" results indicates, that the test compounds have no deviations from Lipinski's rules (LogP $\leq 5$; molecular weight $\leq 500$; ability to be a proton acceptor $\leq 10$; ability to be a proton donor $\leq 5$; bond rotation $\leq 8$ ), as 
Table 1. The results of molecular docking and pharmacological standards

\begin{tabular}{|c|c|c|c|c|}
\hline Compd. & $\mathbf{R}$ & $\mathbf{R}_{1}$ & $\begin{array}{l}\text { Affinity (kcal/mol) } \\
\text { to LOX (soybean) }\end{array}$ & $\begin{array}{l}\text { The main interactions types between compounds, pharmacological } \\
\text { standards and amino acid residues of enzymes }\end{array}$ \\
\hline Proto-catechuic acid & - & - & -5.0 & HIS523a ${ }^{a}$, LEU565 ${ }^{b}$, HIS518 $8^{b}$, ALA561 ${ }^{b}$, LEU773 ${ }^{b}$. \\
\hline NDGA & - & - & -6.9 & ASN556 ${ }^{\mathrm{a}}$, LYS278 ${ }^{\mathrm{a}}$, PHE272 ${ }^{\mathrm{b}}$, VAL26 ${ }^{\mathrm{b}}$, TYR275 ${ }^{\mathrm{b}}$. \\
\hline 1.1 & Me & - & -6.8 & 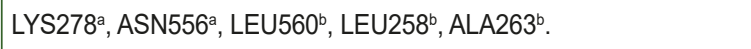 \\
\hline 1.2 & $\mathrm{Ph}$ & - & -6.6 & 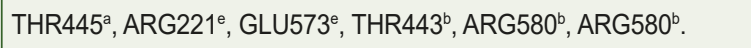 \\
\hline 1.3 & $4-i-\mathrm{PrC}_{6} \mathrm{H}_{4}$ & - & -6.2 & LYS278a, LYS278a, TYR275 \\
\hline 2.1 & $\mathrm{CH}_{3}$ & - & -6.7 & LYS278a , LYS278 ${ }^{a}$, ASN556 $^{a}$, LEU560 $^{b}$, ALA263 $^{b}$. \\
\hline 2.2 & $\mathrm{Ph}$ & - & -6.7 & SER281 ${ }^{a}$, SER564a ${ }^{a}$, ARG252 $^{\mathrm{a}}$, ARG252 $^{\mathrm{b}}$. \\
\hline 2.3 & 4- $\mathrm{MeC}_{6} \mathrm{H}_{4}$ & - & -6.5 & ARG580a , GLU573a, GLU573e, LEU729a, PRO759a. \\
\hline 2.4 & 4-EtC ${ }_{6} \mathrm{H}_{4}$ & - & -6.4 & THR445 a, SER444a, SER444a, LEU729 ${ }^{b}$. \\
\hline 2.5 & 4-i- $\mathrm{PrC}_{6} \mathrm{H}_{4}$ & - & -6.9 & ARG580a, GLU573a , GLU573e, PRO759 ${ }^{\mathrm{b}}$, LEU729 ${ }^{\mathrm{b}}$, ARG731 $^{\mathrm{b}}$. \\
\hline 2.6 & $4-t-\mathrm{BuC}_{6} \mathrm{H}_{4}$ & - & -7.0 & TYR275a $^{\mathrm{a}}$, TYR275 ${ }^{\mathrm{b}}$, ALA263 ${ }^{\mathrm{b}}$. \\
\hline 2.7 & 4-EtOC ${ }_{6} \mathrm{H}_{4}$ & - & -6.2 & ASN556 ${ }^{a}$, TYR275 $^{\mathrm{b}}$, ALA263 $^{\mathrm{b}}$. \\
\hline 2.8 & $\mathrm{Ph}$ & $12-\mathrm{CH}_{3}$ & -7.1 & 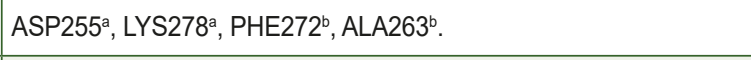 \\
\hline 2.9 & 4- $\mathrm{MeOC}_{6} \mathrm{H}_{4}$ & 10-Me & -5.9 & 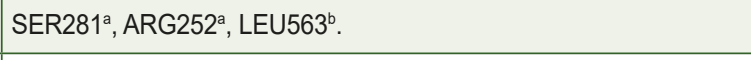 \\
\hline 2.10 & $\mathrm{Ph}$ & $11-\mathrm{F}$ & -6.6 & LYS278'a, TYR275a ${ }^{a}$ ALA263 \\
\hline 2.11 & $\mathrm{Ph}$ & $12-\mathrm{F}$ & -6.6 & 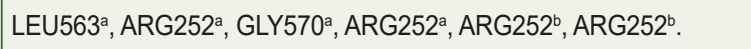 \\
\hline 2.12 & $\mathrm{Ph}$ & $11-\mathrm{F}, 12-\mathrm{F}$ & -6.8 & 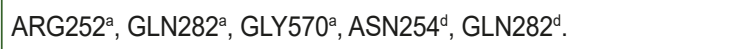 \\
\hline 2.13 & 4-FPh & $11-\mathrm{F}, 12-\mathrm{F}$ & -6.8 & PHE264 ${ }^{d}$, ASN556 $^{d}$, LYS278 $^{a}$, ASP255e $^{e}$, ALA263 $^{\text {b }}$. \\
\hline 2.14 & $\mathrm{Ph}$ & $12-\mathrm{Cl}$ & -6.5 & LEU729b , PRO759 \\
\hline 2.15 & 4- $\mathrm{MeOC}_{6} \mathrm{H}_{4}$ & $12-\mathrm{Cl}$ & -6.0 & LYS278a, PHE272ª ${ }^{\mathrm{b}}$ ALA263 ${ }^{\mathrm{b}}$. \\
\hline 2.16 & $\mathrm{Ph}$ & $12-\mathrm{Br}$ & -6.7 & PHE264 ${ }^{\mathrm{d}}, \mathrm{ARG} 252^{\mathrm{a}}$. \\
\hline 2.17 & 4- $\mathrm{MeOC}_{6} \mathrm{H}_{4}$ & $12-\mathrm{Br}$ & -5.6 & ALA263 ${ }^{\mathrm{b}}, \mathrm{ARG} 252^{\mathrm{a}}$, LYS278 ${ }^{\mathrm{a}}$. \\
\hline 2.18 & thienyl-2 & - & -7.0 & 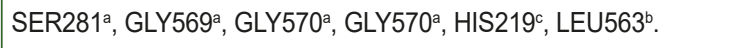 \\
\hline
\end{tabular}

a: hydrogen; b: hydrophobic; c: other (m-Sulfur); d: halogen; e: electrostatic.

well as the pharmacological standard "NDGA". This was an important argument for further biological in vitro research of soybean LOX inhibition.

Conducted in vitro study of soybean LOX-inhibition activity (Table 2) showed, that among substituted pyrrolo[1,2-a] $[1,2,4]$ triazolo[1,5-c]quinazolines highest enzyme-inhibiting activity was revealed by compound 1.1 with methyl substituent in position 2 (inhibition on $25.27 \%$ ). At the same time among substituted pyrrolo[1,2-a][1,2,4]triazino[2,3-c] quinazolines active were compounds 2.4-2.8, 2.13 and 2.18, that exhibited enzyme-inhibiting activity in the range of values $10.03-39.83 \%$. However, the activity of all obtained compounds was lower comparing to reference inhibitor NDGA.

\section{Disscussion}

Among lipooxygenases (LOX), six isoforms are most known (LOX-5, 15-LOX, 15-LOX-2, 12-LOX, 12R-LOX and eLOX3 ), which play an important role in the development of various pathological processes [19]. 5-LOX is a precursor for the synthesis of $\mathrm{B}_{4}$ leukotrienes $\left(\mathrm{LTB}_{4}\right)$, peptidyl leukotrienes $\left(\mathrm{LTC}_{4}\right.$, $\mathrm{LTD}_{4}$ or $\mathrm{LTE}_{4}$ ) and lipoxins that cause inflammatory processes. Compounds were analyzed with the use of molecular docking considering the structural similarity of LOX-5 to soybean lipoxygenase LOX (sLOX) type $1 \mathrm{~b}$ and its role in processes of inflammation. Especially, as 1b sLOX is the molecular biological target, and the high affinity of ligands (the synthesized compounds) to lipoxygenases is one of the desirable characteristics of anti-inflammatory agents.

The visualization of complexes was conducted for evaluation of the effects of structural features of ligands on the level of binding with molecular target. The analysis of the types of main interactions with aminoacid moieties of protein was performed as well (Table 1, Fig. 2). So, visualization of the structure of NDGA with the active site to soybean LOX (Fig. 2) allows to establish, that it has hydrogen and hydrophobic interactions with the amino-acid residues: 
Table 2. The value of the "drug-like" criteria and soybean LOX inhibition

\begin{tabular}{|c|c|c|c|c|c|c|c|c|}
\hline Compnd. & $\log P$ & $\begin{array}{l}\text { Molecular } \\
\text { polar surface } \\
\text { area, } \AA\end{array}$ & $\begin{array}{l}\text { Number of } \\
\text { non-hydro- } \\
\text { gens }\end{array}$ & $\begin{array}{l}\text { Molecular } \\
\text { volume, } A 3\end{array}$ & $\begin{array}{l}\text { Number of hydro- } \\
\text { gen bond acceptors } \\
\text { (groups } \mathrm{N} \text { and } \mathrm{O} \text { ) }\end{array}$ & $\begin{array}{l}\text { Number of hydrogen } \\
\text { bond donors (groups } \\
\mathrm{NH} \text { and } \mathrm{OH} \text { ) }\end{array}$ & $\begin{array}{l}\text { Number } \\
\text { of rotatable } \\
\text { bonds }\end{array}$ & $\begin{array}{l}\text { Soybean LOX } \\
\text { inhibition, (\%) }\end{array}$ \\
\hline NDGA & 3.48 & 80.91 & 22 & 302.37 & 4 & 4 & 5 & 67.19 \\
\hline 1.1 & 0.13 & 88.33 & 21 & 284.27 & 7 & 1 & 1 & 25.27 \\
\hline 1.2 & 2.16 & 88.33 & 26 & 346.35 & 7 & 1 & 2 & 3.56 \\
\hline 1.3 & 3.67 & 88.33 & 29 & 388.43 & 7 & 1 & 3 & 0.00 \\
\hline 2.1 & 0.02 & 105.40 & 23 & 312.29 & 8 & 1 & 1 & 0.00 \\
\hline 2.2 & 1.47 & 105.40 & 28 & 374.36 & 8 & 1 & 2 & 0.00 \\
\hline 2.3 & 1.92 & 105.40 & 29 & 388.38 & 8 & 1 & 2 & 3.78 \\
\hline 2.4 & 2.38 & 105.40 & 30 & 402.41 & 8 & 1 & 3 & 20.81 \\
\hline 2.5 & 2.98 & 105.40 & 31 & 416.44 & 8 & 1 & 3 & 20.63 \\
\hline 2.6 & 3.17 & 105.40 & 32 & 430.46 & 8 & 1 & 3 & 20.53 \\
\hline 2.7 & 1.90 & 114.63 & 31 & 418.41 & 9 & 1 & 4 & 15.42 \\
\hline 2.8 & 1.89 & 105.40 & 29 & 388.38 & 8 & 1 & 2 & 10.03 \\
\hline 2.9 & 1.92 & 114.63 & 31 & 418.41 & 9 & 1 & 3 & 0.00 \\
\hline 2.10 & 1.63 & 105.40 & 29 & 392.35 & 8 & 1 & 2 & 6.41 \\
\hline 2.11 & 1.61 & 105.40 & 29 & 392.35 & 8 & 1 & 2 & 0.00 \\
\hline 2.12 & 1.70 & 105.40 & 30 & 410.34 & 8 & 1 & 2 & 0.00 \\
\hline 2.13 & 1.86 & 105.40 & 31 & 428.33 & 8 & 1 & 2 & 36.33 \\
\hline 2.14 & 2.12 & 105.40 & 29 & 408.80 & 8 & 1 & 2 & 9.46 \\
\hline 2.15 & 2.18 & 114.63 & 31 & 438.83 & 9 & 1 & 3 & 1.79 \\
\hline 2.16 & 2.25 & 105.40 & 29 & 453.25 & 8 & 1 & 2 & 2.37 \\
\hline 2.17 & 2.31 & 114.63 & 31 & 483.28 & 9 & 1 & 3 & 0.00 \\
\hline 2.18 & 1.25 & 105.40 & 27 & 380.38 & 8 & 1 & 2 & 39.83 \\
\hline
\end{tabular}

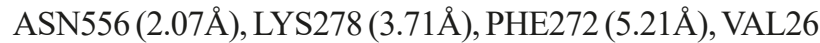

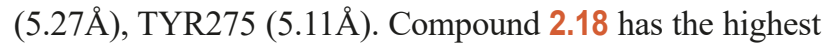
affinity to the soybean LOX target, among the investigated ones. Visualization of this structure with the soybean LOX active site (Fig. 2) showed, that it is characterized by four hydrogen bonds with the amino acid residues: SER281

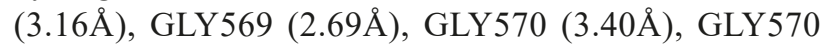

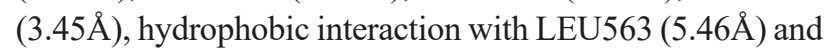
quite strong $\pi$-Sulfur interaction with HIS219 (4.82 $\AA$ ). So, an important aspect of compounds' high affinity to soybean LOX is the presence of several hydrogen bonds, hydrophobic interactions, donor-acceptor interactions due to sulfur and fluorine lone electron pairs (Table 1).

The comparative analysis of "drug-like" results and soybean LOX inhibition has shown, that the lipoxygenase activity depends on molecule lipophilicity and availability of acceptors and donors of hydrogen bond. The last statement agreed with the data of molecular docking (Table 1, Fig. 2). So, substituted pyrrolo[1,2- $a][1,2,4]$ triazino[2,3-c]quinazolines with a fluorine atom (2.13) and a 2-thienyl fragment (2.18) in the molecule inhibit lipoxygenase by $36.33 \%$ and $39.83 \%$ respectively. The increase of lipophilicity promotes higher ability to inhibit soybean LOX (Table 2), which is speaking above derivatives $2.1-2.18$. Thus, compounds 2.4-2.6 inhibit soybean LOX by 20.53-20.81\%. Whereas, for substituted pyrrolo[1,2-a][1,2,4]triazolo[1,5-c]quinazolines which have considerably smaller molecular weight inverse relation is observed. So, compound 1.1 with the indicator of lipophilicity 0.03 inhibits soybean LOX by $25.27 \%$. Increase in lipophilicity (compound 1.2) leads to activity decrease, and in case of compound 1.3 - its total loss.

\section{Conclusions}

The research of the substituted pyrrolo[1,2- $a][1,2,4]$ triazolo(triazino-)[c]quinazolines inhibition ability of soybean LOX as one of possible mechanisms of their activity is proved and conducted. It is shown, that their lipoxygenase activity depends on lipophilicity and is defined by availability in the molecule of donor-acceptor fragments in the molecule, that are capable to form hydrogen and other types of interaction. The specified results are the strong argument for their further study as promising anti-inflammatory agents. It is planned the in vivo study of anti-inflammatory activity and toxic effects for the most active compounds. 


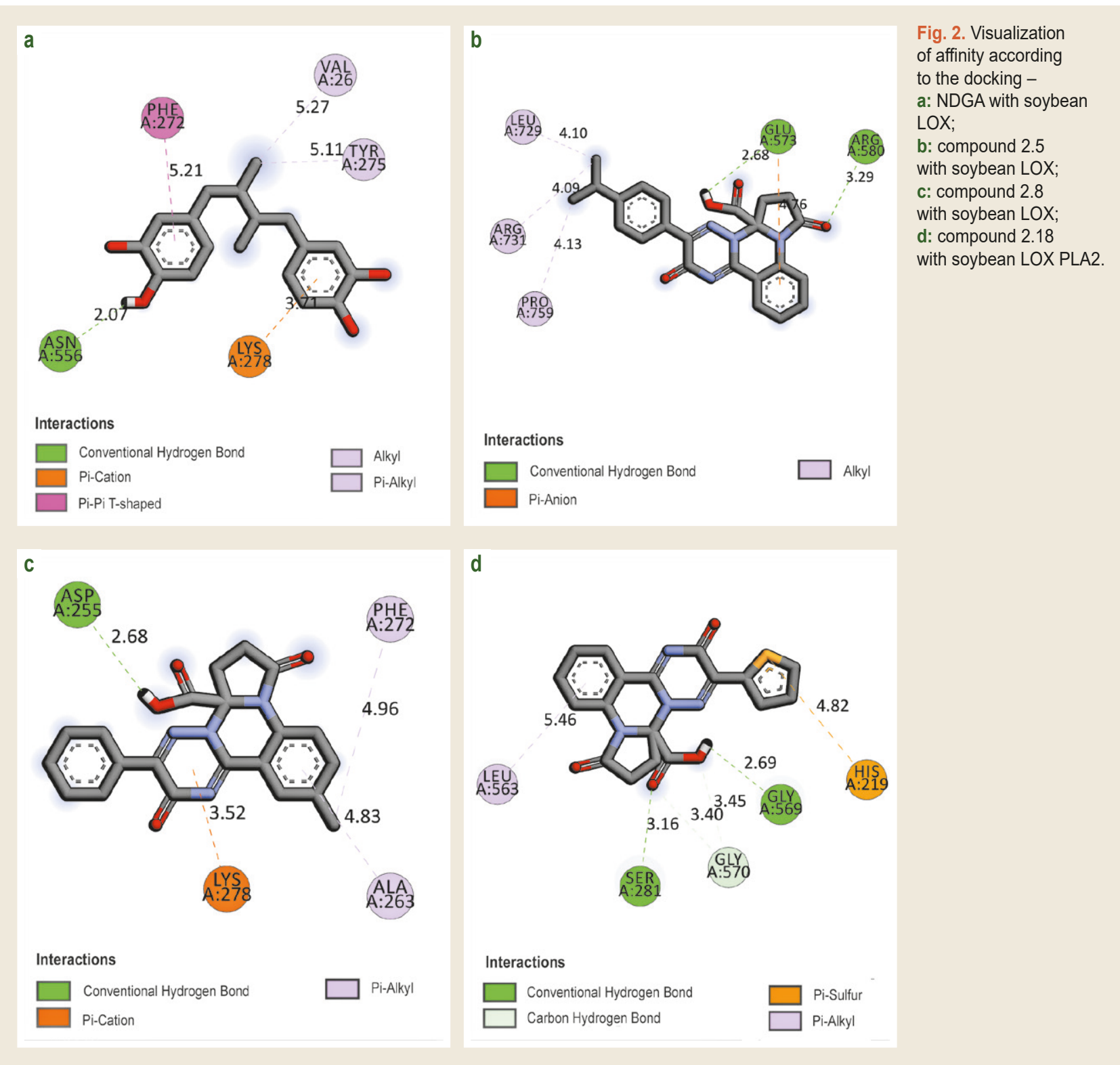

\section{Funding}

The work was carried out on the budgetary theme of the Ministry of Health of Ukraine "Purposeful search for anti-inflammatory agents among condensed and spiro-condensed quinazoline derivatives" (№ state registration 0118U004370; period of study 2018-2020).

Conflicts of interest: authors have no conflict of interest to declare. Консрлікт інтересів: відсутній.

Information about authors:

Stavytskyi V. V., PhD-student of the Department of Organic and Bioorganic Chemistry, Zaporizhzhia State Medical University, Ukraine. Nosulenko I. S., PhD, Senior Lecturer of the Department of Pharmacognosy, Pharmacology and Botany, Zaporizhzhia State Medical University, Ukraine.

Portna O. O., PhD, Associate Professor of the Department of Pharmaceutical Chemistry, Zaporizhzhia State Medical University, Ukraine.

Shvets V. M., Dr.hab., Professor, Department of Biochemistry and Laboratory Diagnostics, Zaporizhzhia State Medical University, Ukraine.
Voskoboynik O. Yu., Dr.hab., Associate Professor, Department of Organic and Bioorganic Chemistry, Zaporizhzhia State Medical University, Ukraine.

Kovalenko S. I., Dr.hab., Professor, Head of the Department of Organic and Bioorganic Chemistry, Zaporizhzhia State Medical University, Ukraine.

\section{Відомості про авторів:}

Ставицький В. В., аспірант каф. органічної і біоорганічної хімії, Запорізький державний медичний університет, Україна. Носуленко І. С., канд. фарм. наук, старший викладач

каф. фрармакогнозії, фрармакології та ботаніки, Запорізький державний медичний університет, Україна.

Портна О. О., канд. фарм. наук, доцент каф. фрармацевтичної хімії, Запорізький державний медичний університет, Україна.

Швець В. М., д-р біол. наук, профресор каф. біохімії та лабораторної діагностики, Запорізький державний медичний університет, Україна. Воскобойнік О. Ю., д-р фарм. наук, доцент каф. органічної і біоорганічної хімії, Запорізький державний медичний університет, Україна.

Коваленко С. І., д-р фрарм. наук, профресор, зав. кафр. органічної і біоорганічної хімії, Запорізький державний медичний університет, Україна. 
Сведения об авторах:

Ставицкий В. В., аспирант каф. органический и биоорганической химии, Запорожский государственный медицинский университет, Украина.

Носуленко И. С., канд. фрарм. наук, старший преподаватель каф. органический и биоорганической химии, Запорожский государственный медицинский университет, Украина.

Портная Е. А., канд. фрарм. наук, доцент каф. фрармацевтической химии, Запорожский государственный медицинский университет, Украина.

Швец В. Н., д-р биол. наук, профессор каф. биохимии и лабораторной диагностики, Запорожский государственный медицинский университет, Украина.

Воскобойник А. Ю., д-р фарм. наук, доцент каф. органической и биоорганической химии, Запорожский государственный медицинский университет, Украина.

Коваленко С. И., д-р фарм. наук, профессор, зав. каф. органической и биоорганической химии, Запорожский государственный медицинский университет, Украина.

\section{References}

[1] Krogsgaard-Larsen, P., Liljefors, T., \& Madsen, U. (2002). Textbook of Drug Design and Discovery (3rd ed.). Washington, DC: Taylor \& Francis.

[2] Keseru, G. M., \& Makara, G. M. (2009, Mar). The influence of lead discovery strategies on the properties of drug candidates. Nature $R e-$ views Drug Discovery, 8(3), 203-212. https://doi.org/10.1038/nrd2796

[3] Hajduk, P. J., \& Greer, J. (2007). A decade of fragment-based drug design: strategic advances and lessons learned. Nature Reviews Drug Discovery, 6(3), 211-219. https://doi.org/10.1038/nrd2220

[4] Landry, Y., \& Gies, J. P. (2008). Drugs and their molecular targets: an updated overview. Fundamental \& Clinical Pharmacology, 22(1), 1-18. https://doi.org/10.1111/j.1472-8206.2007.00548.x

[5] Jung, H. J., \& Kwon, H. J. (2015). Target deconvolution of bioactive small molecules: the heart of chemical biology and drug discovery. Archives of Pharmacal Research, 38(9), 1627-1641. https://doi. org/10.1007/s12272-015-0618-3

[6] Lee, H., \& Lee, J. W. (2016). Target identification for biologically active small molecules using chemical biology approaches. Archives of Pharmacal Research, 39(9), 1193-1201. https://doi.org/10.1007/ s12272-016-0791-z

[7] Yakubovska, V. V., Seredinska, N. M., Voskoboynik, O. Yu., Stepanyuk, G. I., \& Kovalenko, S. I. (2016). Spriamovanyi poshuk i kharakterystyka protyzapalnoi aktyvnosti natrii (3-R-2-okso-2H-[1,2,4]triazino[2,3-c]khinazolin-6-il)alkilkarboksylativ ta yikh halohenovmisnykh analohiv [Purposeful search and characteristic of anti-inflammatory activity of sodium (3-R-2-oxo-2H-[1,2,4]triazino[2,3-c]quinazolin-6-yl) alkylcarboxylates and their halogen containing analogues]. Current issues in pharmacy and medicine: science and practice, (1), 60-66. [in Ukrainian]. https://doi.org/10.14739/2409-2932.2016.1.62036

[8] Voskoboynik, O. Yu., Starosyla, S. A., Protopopov, M. V., Volynets, H. P., Shyshkina, S. V., Yarmoliuk, S. M., \& Kovalenko, S. I. (2016). Synthesis, anticancer and FGFR1 inhibitory activity of isoindolo[2,1-a][1,2,4]triazino[2,3-c]quinazoline derivatives. Medychna ta klinichna khimiia, 18(1), 5-18. https://doi.org/10.11603/mcch.2410681X.2016.v0.i1.6123

[9] Voskoboynik O. Yu., Kovalenko S. I., \& Shishkina S. V. (2016). 3-R 8- $\mathrm{R}_{2}-10-\mathrm{R}_{3}-2 \mathrm{H}$-benzo[e][1,2,4]triazino[2,3-c][1,2,3]triazin-2-ones novel high electro-deficient heterocyclic compounds with promising anticancer activity. Heterocyclic Communications, 22(3), 137-141. https://doi.org/10.1515/hc-2015-0190

[10] Antypenko, O. M., Kovalenko, S. I., Karpenko, O. V., Nikitin, V. O., \& Antypenko, L. M. (2016). Synthesis, Anticancer, and QSAR Studies of 2-Alkyl(aryl,hetaryl)quinazolin-4(3H)-thione's and 1,2,4 Triazolo 1,5-c quinazoline-2-thione's Thioderivatives. Helvetica Chimica Acta, 99(8), 621-631. https://doi.org/10.1002/hlca.201600062

[11] Antypenko, O. M., Kovalenko, S. I., Rasulev, B. F., \& Leszczynsk, J. (2016). Synthesis of $6-N$ - $R$-tetrazolo[1,5-c]quinazolin-5(6H)-ones, anticancer activity and QSAR modeling. Acta Chimica Slovenica, 63(3), 638-645. https://doi.org/10.17344/acsi.2016.2464

[12] Kolomoets, O. S., Voskoboynik, O. Yu., Antypenko, O. M., Berest, G. G., Nosulenko, I. S., Palchikov, V. O., Karpenko, O. V., \& Kovalenko, S. I. (2017). Desing, synthesis and anti-inflammatory activity of dirivatives 10-R-3-aryl-6,7-dihydro-2H-[1,2,4]triazino[2,3-c] quinazolin-2-ones of spiro-fused cyclic frameworks. Acta Chimica Slovenica, 64(4), 902-910. https://doi.org/10.17344/acsi.2017.3575

[13] Martynenko Yu. V., Kazunin M. S., Nosulenko I. S., Berest G. G., Kovalenko S. I., Kamyshnyi O. M., \& Polishchuk N. M. (2018). 2-([1,2,4] triazolo[1,5-c]quinazoline-2-yl-)alkyl-(alkaryl-, aryl-)-amines and their derivatives. Message 2. The synthesis of (3H-quinazoline-4-ylidene) hydrazides $N$-protected aminoacids, using a variety of amine-protecting approaches. Physico-chemical properties and biological activity of the synthesized compounds. Zaporozhye medical journal, 20(3), 413-420. https://doi.org/10.14739/2310-1210.2018.3.130544

[14] Voskoboynik, O. Yu., Shishkina, S. V., \& Kovalenko, S. I. (2018). $[1,2,4]$ Triazino[2,3-c]quinazolines 3 . Structure and anticancer activity of products obtained from reaction of 3-(2-aminophenyl)-6$\mathrm{R}$-1,2,4-triazin-5(2H)-ones with aryl iso(thio)cyanates. Chemistry of Heterocyclic Compounds, 54(7), 717-728. https://doi.org/10.1007/ s10593-018-2338-3

[15] Martynenko, Yu. V., Antypenko, O. M., Nosulenko, I. S., Berest, G. G., \& Kovalenko, S. I. (2019). Directed search of anti-inflammatory agents among ( $3 \mathrm{H}$-quinazoline-4-ylidene)hydrazides of $\mathrm{N}$-protected amino acids and their heterocyclization products. Anti-Inflammatory \& Anti-Allergy Agents in Medicinal Chemistry, 18(2). 1-12. https://doi. org/10.2174/1871523018666190115092215

[16] Stavitskiy, V. V., Voskoboinik, O. Yu., Nosulenko, I. S., Klimova, O. O., Brazhko, O. A., \& Kovalenko, S. I. (2019). Zamisheni 3-R-7,8-digidro2H-pirolo[1,2-a][1,2,4]triazino[2,3-c]hinazolin-5a(6H)-alkil-karbonovi kysloty - perspektyvnyi klas malotoksychnykh protyzapalnykh ahentiv [Substituted 3-R-7,8-dihydro-2H-pyrrolo[1,2-a][1,2,4]triazino[2,3-c] quinazolin-5a- $(6 \mathrm{H})$-alkyl-carboxylic acids - promising class of low-toxic anti-inflammatory agents] Farmatsevtychnyi chasopys, (3), 5-12. [in Ukrainian]. https://doi.org/10.11603/2312-0967.2019.3.10468

[17] Mashima, R., \& Okuyama, T. (2015). The role of lipoxygenases in pathophysiology; new insights and future perspectives. Redox Biology, 6, 297-310. https://doi.org/10.1016/j.redox.2015.08.006

[18] Voskoboinyk, O. Yu., Kovalenko, S. I., Malkova, T. S., \& Stavytskyi, V. V. (2018). Pirolo[1,2-a][1,2,4]tryazyno[2,3-c]khinazoliny ta izoindolo[2,1-a][1,2,4]tryazyno[2,3-c]khinazoliny [Pyrrolo [1,2-a] [1,2,4] triazino [2,3-c]quinazolines and isoindolo [2,1-a][1,2,4] triazino [2,3-c] quinazolines]. Ukraine Patent UA 118196. Retrieved from https://base. uipv.org/searchINV/search. php?action=viewdetails\&IdClaim=253331 [in Ukrainian].

[19] Worldwide Protein Data Bank. (n.d.). Protein Data Bank (PDB) [Database]. Retrieved from http://www.pdb.org

[20] ChemAxon. (2015). MarvinSketch, Version 6.3.0. [Software]. Retrieved from http://www.chemaxon.com

[21] Trott, O., \& Olson, A. J. (2010). Software News and Update AutoDock Vina: Improving the Speed and Accuracy of Docking with a New Scoring Function, Efficient Optimization, and Multithreading. Journal of Computational Chemistry, 31(2), 455-461. https://doi.org/10.1002/ jcc. 21334

[22] Biovia. (2019). Discovery Studio Visualizer, v 19.1.0.18287 [Software]. Retrieved from http://www. 3dsbiovia.com/

[23] Molinspiration Cheminformatics. (n.d.). Calculation of Molecular Properties and Bioactivity Score [Computer software]. Retrieved from http://www.molinspiration.com/cgi-bin/properties

[24] Pontiki, E., \& Hadjipavlou-Litina, D. (2007). Synthesis and pharmacochemical evaluation of novel aryl-acetic acid inhibitors of lipoxygenase, antioxidants, and anti-inflammatory agents. Bioorganic \& Medicinal Chemistry, 15(17), 5819-5827. https://doi.org/10.1016/j. bmc.2007.06.001

[25] Korobko, D., Hadjipavlou-Litina, D. J., \& Logoyda, L. (2018). Antioxidant and anti-inflammatory properties of a series of new 7,8-disubstituted theophylline containing a pyrazole ring. Asian Journal of Pharmaceutical and Clinical Research, 11(6), 448-450. http://dx.doi. org/10.22159/ajpcr.2018.v11i6.25990 